\title{
Evaluation of color-coded drug labeling to identify endovenous medicines
}

\author{
Avaliação da rotulagem com código de cores para identificação de medicamentos endovenosos \\ Evaluación de los etiquetados con código de colores para la identificación de medicamentos endovenosos
}

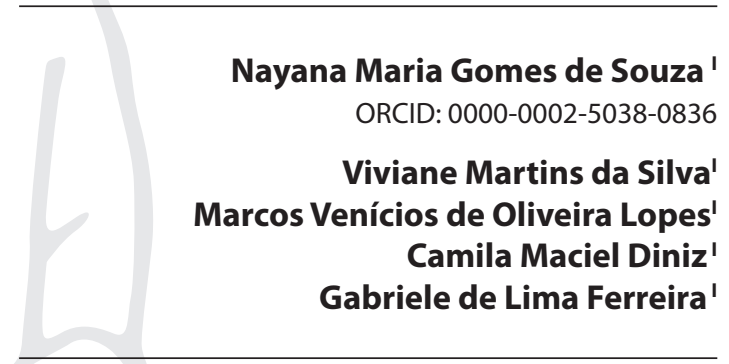

'Universidade Federal do Ceará. Fortaleza, Ceará, Brasil

How to cite this article: Nayana MGS, Silva VM, Lopes MVO, Diniz CM, Ferreira GL. Evaluation of color-coded drug labeling to identify endovenous medicines. Rev Bras Enferm. 2019;72(3):715-20. doi: http://dx.doi.org/10.1590/0034-7167-2018-0242

Corresponding Author: Nayana Maria Gomes de Souza E-mail: nayanamgs@hotmail.com

Submission: 05-08-2018 Approval: 01-21-2019

\section{ABSTRACT}

Objective: To analyze the opinion of nursing professionals on the design, practicality of use and the usefulness of color-coded drug labeling in a pediatric intensive care unit. Methods: A cross-sectional study with 42 nursing professionals. A structured questionnaire was used based on a five-level Likert scale. To assess the proportions, a binomial test was used. Results: Concordance ratio $>0.8$ for all propositions related to design, practicality and most of the propositions related to error prevention. Conclusion: According to the opinion of the nursing team, the implemented technology has an adequate design, as well as being practical and useful in the prevention of medication errors in the population at the ICU.

Descriptors: Medication Errors; Patient Safety; Intensive Care Units; Drug Labeling; Technology.

\section{RESUMO}

Objetivo: Analisar a opinião dos profissionais de enfermagem sobre o design, a praticidade do uso e a utilidade da rotulagem com código de cores em uma unidade de terapia intensiva pediátrica. Método: Estudo transversal, realizado com 42 profissionais de enfermagem. Utilizou-se um questionário estruturado com base em uma escala Likert de cinco níveis. Para a análise das proporções, utilizou-se o teste binomial. Resultados: Houve proporção de concordância $>0,8$ para todas as proposições relacionadas ao design, à praticidade do uso e à maioria das proposições relacionadas à prevenção de erros. Conclusão: De acordo com a opinião da equipe de enfermagem, frente ao objeto de estudo, a tecnologia implementada tem design adequado, além de ser prática e útil na prevenção de erros de medicamentos em população atendida na UTI.

Descritores: Erros de Medicação; Segurança do Paciente; Unidades de Terapia Intensiva; Rotulagem de Medicamentos; Tecnologia.

\section{RESUMEN}

Objetivo: Analizar la opinión de los profesionales de Enfermería acerca del diseño, la practicidad del uso y la utilidad de los etiquetados con código de colores en una unidad de terapia intensiva pediátrica. Método: Estudio transversal, realizado con 42 profesionales de enfermería. Se utilizó un cuestionario estructurado basado en una escala Likert de cinco niveles. Para el análisis de las proporciones, se utilizó la prueba binomial. Resultados: Se encontró la proporción de concordancia $>0,8$ para todas las proposiciones relacionadas con el diseño, la practicidad del uso y la mayoría de las proposiciones relacionadas con la prevención de errores. Conclusión: Según la opinión del equipo de enfermería frente al objeto de estudio, la tecnología implementada tiene un diseño adecuado, además de ser práctica y útil en la prevención de errores de medicamentos en población atendida en la UTI.

Descriptores: Errores de Medicación; Seguridad del Paciente; Unidades de Terapia Intensiva; Etiquetados de Medicamentos; Tecnología. 


\section{INTRODUCTION}

Drug therapy is widely used in Intensive Care Units, and in a larger amount when compared to other hospitalization units. This is due to the nature of care provided, which is characterized by severe clinical conditions and complex interventions ${ }^{(1)}$.

The drug administration process is prone to errors and there are several reasons for this adverse event to happen, which can be at any stage of the medication system and involves any of the numerous medications available, including those classified as high-alert medications ${ }^{(2)}$.

High-risk medications, also known as high-alert or potentially dangerous medications, are those with the highest potential for serious harm because they increase the length of hospital stay and recovery, expose patients to a greater number of procedures and therapies. In addition, they may cause more serious consequences for patients, such as death, in which an error is incurred in the course of its use ${ }^{(3-4)}$.

The numbers draw attention to this reality and warn of a health problem that can be avoided. Errors associated with the medication process can affect up to 947 of 1,000 patients per day in intensive care units and raise hospital costs by up to U\$2.8 million $^{(5)}$. Previous studies have also shown that out of every five drugs given to patients, an error occurs ${ }^{(6-7)}$.

To reduce these complications, some health technologies have been conquering space in Nursing. The technology is present in all stages of care, considered both a process and a product ${ }^{(8)}$. The development and implementation of care technology in clinical practice can benefit the quality of the care provided and the occurrence of the smallest number of preventable errors.

One of these technologies corresponds to the use of adhesive labels to identify the devices that take the drugs to patients. It was developed by the International Society for Anaesthetic Pharmacology ${ }^{(9)}$. Different colors and shapes are used, considering the drug class, as well as the location of the text and the font-size. In 2008, the International Organization for Standardization (ISO) published standard ISO 26825, which refers to the standardization drug labels based on the method described. In 2013, the Australian Commission on Safety and Quality in Health Care published the recommendations to monitor the identification of drugs to be used in all Australian health services based on color-coded drug labeling ${ }^{(10)}$.

The standardization of color-coded labeling is used in intensive care units in Europe and has a major impact on improving patient safety and reducing medication errors ${ }^{(11)}$.

In Brazil, high-alert drugs are identified according to the standardization established by the hospital, which may make it difficult to monitor potentially dangerous drugs. The use of color-coded labels is not widespread and there is no standard policy for labeling these drugs. In this light, scientific studies dealing with the use of these technologies must be developed to contribute to patient safety ${ }^{(12)}$.

\section{OBJECTIVE}

Analyze the opinion of nursing professionals on the design, practicality of use and the usefulness of color-coded drug labeling in a pediatric intensive care unit.

\section{METHOD}

\section{Ethical aspects}

The study was registered in the Plataforma Brasil (Brazil Platform: a national and unified database for scientific research) and submitted and approved by the Committee of Ethics in Research with Human Beings, Hospital de Messejana Dr. Carlos Alberto Studart Gomes.

\section{Research design, place and period}

This is a cross-sectional study, developed in a pediatric intensive care unit (ICU) of a tertiary referral hospital in pediatric cardiac surgeries in the state of Ceará. This unit has eight beds and a monthly average of 25 pediatric admissions for post-surgical treatment related to congenital heart diseases. Data collection occurred between January and March 2015.

\section{Population, sample, inclusion and exclusion criteria}

The study population corresponded to Nursing professionals working in the intensive care unit mentioned. For the sample, considering the staff of the unit, all nursing professionals of the pediatric postoperative ICU were chosen. For this, the following inclusion criteria were listed: holding a degree in Nursing and/or being a nurse; assisting the mentioned unit; and being available for data collection. The sample totaled 42 participants.

\section{Study protocol}

Color-coded labels were implemented at the study site in September 2014 and their development was based on the study proposed by Porat et al. ${ }^{(9)}$. The labels were created in three formats, to identify all the devices used in the administration of intravenous drugs such as infusion pumps, syringes and saline solution (Figures 1, 2 and 3). For the last two devices, the same label design was used.

The colors were defined according to the drug class, previously established by the American Society of Anesthesiology ${ }^{(13)}$ and by ISO 26825. As for the design, the background color of the labels was white, and the drug nomenclature was highlighted with the referring color to its drug class.

After making the labels, on-site trainings and lectures were conducted with the professionals for the proper use of and correct filling in the technology. The evaluation of the labeling system was carried out three months after the implementation of this technology.

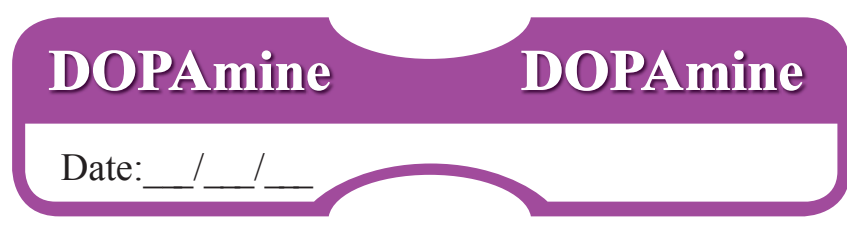

Source: Adapted from the study by Porat et al. (2009)(9).

Figure 1 - Example of label designed for the kits for each drug, size $5 \mathrm{~cm} \mathrm{x}$ $1.5 \mathrm{~cm}$, Times New Roman font 
Patient:

Bed:

\section{DOPAmine}

Dilution:
Date:

Flow:
Time:

Sig.
Source: Adapted from the study by Porat et al. (2009) ${ }^{(9)}$

Figure 2 - Example of label designed for the kits for infusion pumps, size $8.5 \mathrm{~cm} \times 5 \mathrm{~cm}$, Times New Roman font

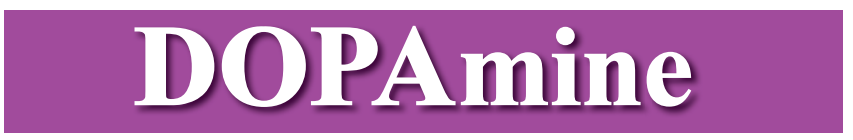

Source: Adapted from the study by Porat et al. (2009)(9).

Figure 3 - Example of label designed for the syringes and saline solutions for each drug, size $8.5 \mathrm{~cm} \times 2.5 \mathrm{~cm}$, Times New Roman font

Chart 1 - Standardized colors for the respective drug classes.

\begin{tabular}{|c|c|c|}
\hline Drug Class & Examples & Standardized color \\
\hline Induction Agents & Thiopental, Ketamine & Yellow \\
\hline Tranquilizers & Dizepam, Midalozam & Orange \\
\hline Muscle Relaxants & Vecuronium, Pancuronium & Fluorescent red \\
\hline Narcotics & Fentanyl, Morphine & Blue \\
\hline $\begin{array}{c}\text { Narcotic } \\
\text { Antagonists }\end{array}$ & Narcan/Naloxone & $\begin{array}{c}\text { White and blue } \\
\text { diagonal stripes }\end{array}$ \\
\hline $\begin{array}{c}\text { Vasopressors } \\
\text { Hypotensive } \\
\text { Agents }\end{array}$ & Adrenaline, Dopamine & \begin{tabular}{c} 
Violet \\
\hline Nocal Anesthetics
\end{tabular} \\
\hline $\begin{array}{c}\text { Anticholinergic } \\
\text { Agents }\end{array}$ & Lidocaine & $\begin{array}{c}\text { White and violet } \\
\text { diagonal stripes }\end{array}$ \\
\hline
\end{tabular}

Source: Adapted from the American Society for Testing and Materials (1994)(14)

A questionnaire addressing color-coded labeling technology was used. This instrument was derived from an adaptation of the questionnaire proposed by the Australian Commission on Safety and Quality in Health Care (2013) ${ }^{(10)}$.

The questionnaire consists of two parts: the first, containing the sociodemographic data of participants; the second, with 15 items referring to the evaluation of the color-coded labeling system implemented at the study place, to know the perception of professionals regarding the design, practicality of the use, and usefulness of this labeling system in the prevention of errors of medication administration in the population served at the ICU. A Likert scale was used to obtain the answers with five degrees of variation, considering grade 5 - totally disagree (TD) and the extreme opposite, grade 1 - fully agree (FA). The scores were of $1.0 ; 0.75 ; 0.5 ; 0.25$ and 0 , to fully agree, partially agree, indifferent, partially disagree and totally disagree, respectively.

The researchers conducted a pilot test with four collaborators, to verify the clarity and compression of the instrument items. The application of the questionnaire did not lead to modifications or exclusions of items. The participants of the pilot test were excluded from the total sample.

The data collection instrument was distributed to professionals who agreed to participate and signed the Informed Consent Term. They answered the questionnaire individually, during working hours, returning it immediately to the researcher.

\section{Results analysis and statistics}

The data collected were typed into the Microsoft Excel for Mac 2011 worksheet, summarized and presented descriptively by means of frequency distribution, absolute values, averages and standard deviation. A proportional analysis was performed using the binomial test. In this study, the proportion of nurses who considered the labeling system as adequate/practical/useful lower than 0.8 was considered as an alternative hypothesis.

\section{RESULTS}

The sample of this study was characterized by participants aged between 21 and 52, with a mean age of 32.33 years old (S.D. \pm 7.88 ) and the median of 34 years old; $100 \%$ were female; $35.7 \%$ were nurses and $64.3 \%$ were licensed practical nurses. Regarding the time in the ICU, a median of 4 years $(p<0.05)$ was obtained.

In this analysis, the agreement of the nursing team in front of the object of study is shown. The higher the score obtained from the $\mathrm{p}$-value, the more favorable is the attitude of the subject regarding the usefulness of the color-coded drugs labeling on patient safety and vice versa.

The data in the table below refer to the analysis of the propositions from the instrument of data collection (Table 1).

In the analysis of the design-related propositions, the values of the items were significant, considering the proportion of the nursing team of the ICU under study was above $80 \%(p=0.9999)$, which makes this item appropriate.

Regarding the agreement of the propositions as for error prevention, the values were significant in most items $(p=1)$, except in the proposition "Is it necessary to handle the drug label to identify an E-V line?" that obtained p value $<0.0001$. Although the value obtained for this proposition is not statistically significant $(p<0.8)$, in clinical practice it indicates a positive sign since the use of color-coded labels facilitates visualization and reduces the time needed to differentiate intravenous lines. Thus, it is not necessary to handle the drug label to identify what is being infused, as is done on the labeling without color coding, which facilitates the monitoring of intravenous therapy.

The propositions regarding the practicality of use also presented an adequate evaluation. The values of the proportion among professionals were greater than $80 \%(p=1)$.

As for the time to label all drugs, by the patient's bed, participants were questioned about how long this task needed to be performed and a median of two minutes (IQ 0 ) was obtained. According to the nursing professionals'statements, the labeling system contributed positively to nursing care. It reduced the average time of performance for general tasks. The nursing team used a white-backed adhesive tape before using color-coded labeling, and they needed to write the drug nomenclature, dosage, date, time, and dilution for each drug prepared, thus demanding more time on general tasks. 
Table 1 - Distribution of the results of the propositions referring to the perception of nursing professionals about the use of color-coded labeling at the study site. Fortaleza City, state of Ceará, Brazil, $2016(n=42)$

\begin{tabular}{|c|c|c|c|c|}
\hline Propositions & Median & IQR & $\mathbf{C l}$ & P Value \\
\hline \multicolumn{5}{|l|}{ Design } \\
\hline Is the use of the drug nomenclature appropriate? & 0.75 & 0.25 & $0.82-0.99$ & 0.999 \\
\hline Are the dimensions of the label adequate? & 1 & 0 & $0.89-1.0$ & 1 \\
\hline Is the color coding in accordance with the drug class/action acceptable? & 1 & 0 & $0.89-1.0$ & 1 \\
\hline Is the text on labels readable? & 1 & 0 & $0.89-1$ & 1 \\
\hline \multicolumn{5}{|l|}{ Error prevention } \\
\hline $\begin{array}{l}\text { Is the capital letter used at the beginning of the drug nomenclature on labels helping to differentiate the } \\
\text { names of similar drugs? }\end{array}$ & 1 & 0 & $0.89-1$ & 1 \\
\hline Was the place of the color used useful to identify the drug? & 1 & 0 & $0.89-1$ & 1 \\
\hline $\begin{array}{l}\text { Was the standardization of red lettering on a white background in high-risk drugs with no color coding } \\
\text { useful to help in their identification? }\end{array}$ & 1 & 0 & $0.89-1$ & 1 \\
\hline Is it necessary to handle the drug label to identify an E-V line? & 0 & 0.25 & $0-0.10$ & $<0.0001$ \\
\hline \multicolumn{5}{|l|}{ Practicality of use } \\
\hline Are the labels long-lasting throughout their use? & 1 & 0 & $0.89-1$ & 1 \\
\hline Does is make the identification of $\mathrm{E}-\mathrm{V}$ lines, infusion pumps and saline solution pouches easier? & 1 & 0 & $0.89-1$ & 1 \\
\hline Is it more helpful to have pre-printed labels rather than handwritten labels? & 1 & 0 & $0.89-1$ & 1 \\
\hline Does the range of labels available cover most drugs administered through continuous infusion at the ICU? & 1 & 0 & $0.89-1$ & 1 \\
\hline
\end{tabular}

Note: *binomial test; IQR - interquartile range; $\mathrm{Cl}$ - confidence interval at $95 \%$.

In general analysis, there was positive agreement in all the propositions related to the design and practicality of use. Most of the propositions related to error prevention indicated that color-coded labeling is a good tool for monitoring intravenous drug therapies.

\section{DISCUSSION}

The occurrence of iatrogenic events in care endangers the lives of patients at received the attention of nurses in the search for care that ensure the lesser risks possible ${ }^{(15)}$. Health care, free from risks and failures to patients, is a goal to be achieved by health professionals and a commitment to professional training ${ }^{(16)}$.

The design of the labels implemented in care was evaluated to check if its presentation was clear and easy to understand. The suitability of label size and color choice was checked. Each of these items was considered adequate by nursing professionals. Although all design items have achieved a satisfactory response, a study that also evaluated the relevance of label templates, based on the same proposal, demonstrated that there were problems with the design, especially in relation to the selected colors, because the color of the drug label identified a category of drugs but did not necessarily identify a specific drug ${ }^{(17)}$.

Drug incidents occur independently of the route of administration. Nonetheless, the intravenous route exposes patients to a higher risk ${ }^{(18)}$. A Spanish study found that $50 \%$ of medication errors occurred when using the IV route ${ }^{(19)}$. In a hospital in Australia, 293 incidents with patients were reported, 24\% of which were drug-related and $35 \%$ related to the IV ${ }^{(20)}$.

During the analysis of nursing professionals' opinions on the causal factors of errors in medication administration it was found that administering drugs in the wrong route was present in $17 \%$ of the answers ${ }^{(21)}$. Recognize that medication errors are frequent and identify their patterns and causes in the daily practice of child care are only the first step to reduce their occurrence risks ${ }^{(22)}$.

Regarding error prevention, participants consider color-coded labeling adequate in detecting failures in the administration and monitoring of continuous infusion medicines, preventing errors in the process. Another study with a similar research design obtained $93 \%$ of favorable results of the Nursing team when finding that there was improvement to identify the drug administration errors using this technology. According to the findings, this labeling system facilitates the orientation and identification of errors in drug administration in wrong routes ${ }^{(9)}$.

This fact can be justified due to the expectation to guarantee the best result within the clinical conditions and the severity of patients in intensive care units, with the lowest possible complication rates resulting from the procedures performed ${ }^{(23-24)}$. Technologies able to innovate care will always find receptivity by professionals, as well as an environment conducive to their application in the network of health care ${ }^{(25)}$.

Regarding the practicality of use of color-coded labels in continuous infusion medicines, the participants considered this technology useful, making the work of nursing professionals easier for its application. In accordance with these findings, one study emphasized the accuracy and speed of drug delivery due to color-coded labeling in simulated situations of high stress, compared to simple labels made of white tape or simply paper. The group that used white labels failed to distinguish different drug groups, especially in critical situations ${ }^{(26)}$.

\section{Contributions to the Nursing, Health or Public Policy fields}

The evaluation of a technology is of utmost importance to test its quality and suitability for the purpose for which it is intended. Today, there is a growing need to use instruments produced and 
tested with scientific rigor, to provide a better quality of Nursing performance in the different care settings.

\section{Study limitations}

The results found in this study should be considered with caution, considering the limited number of the sample used. It may not correspond to the generalization of the data obtained.

\section{CONCLUSION}

Research identified that nursing professionals agree on the relevance of the use of color-coded drug labeling system. This technology was considered adequate in relation to the design and the practicality of use. Moreover, it is useful to prevent drug administration errors in the population served at the ICU.

\section{REFERENCES}

1. Forte EC, Pire DEP, Padilha MI, Martins MMFP. Medication errors and consequences for nursing professionals and clients: an exploratory study. Texto Contexto Enferm [Internet]. 2017 [cited 2018 Feb 12];26(2):e01400016. Available from: http://www.scielo.br/pdf/tce/v26n2/ pt_0104-0707-tce-26-02-e01400016.pdf

2. Bohomol E. Medication errors: descriptive study of medication classes and high-alert medication. Esc Anna Nery [Internet]. 2014 [cited 2018 Feb 12];18(2):311-6. Available from: http://dx.doi.org/10.5935/1414-8145.20140045

3. Leufer T; Cleary-Holdforth J. Let's do no harm: medication errors in nursing: Part 1. Nurse Educ Pract [Internet]. 2013 [cited 2018 Feb 12];13(3):213-6. Available from: http://dx.doi.org/10.1016/j.nepr.2013.01.013

4. Institute for Safe Medication Practices. ISMP High-Alert Medications [Internet]. 2012 [cited 2018 Feb 12]. Available from: http://www.ismp. org/tools/ institutionalhighAlert.asp

5. Latif A, Rawat N, Pustavoitau A, Pronovost PJ, Pham JC. National Study on the distribution, causes, and consequences of voluntarily reported medication errors between the ICU and non-ICU settings. Crit Care Med [Internet]. 2013 [cited 2018 Feb 12];41(2):389-98. Available from: http://dx.doi.org/10.1097/CCM.0b013e318274156a

6. Keers N, Williams SD, Cooke J \& Ashcroft DM. Prevalence and nature of medication administration errors in health care settings: a systematic review of direct observational evidence. Ann Pharmocother [Internet]. 2013 [cited 2018 Feb 12];47(2):237-56. Available from: http://dx.doi. org/10.1345/aph.1R147

7. Härkänen $\mathrm{M}$, Ahonen J, Kervinen $\mathrm{M}$, Turunen $\mathrm{H}$, Vehvilainen-Julkunen $\mathrm{K}$. The factors associated with medication errors in adult medical and surgical inpatients: a direct observation approach with medication record reviews. Scand J Caring Sci [Internet]. 2015 [cited 2018 Feb 12];29:297-306. Available from: http://dx.doi.org/10.1111/scs.12163

8. Nietsche EA, Teixeira E, Medeiros HP, editors. Tecnologias cuidativo-educacionais: Uma possibilidade para o empoderamento do (a) enfermeiro (a)? Porto Alegre (RS): Moriá; 2014.

9. Porat N, Bitan Y, Shefi D, Donchin Y, Rozenbaum H. Use of colour-coded labels for intravenous high-risk medications and lines to improve patient safety. Qual Saf Health Care [Internet]. 2009 [cited 2018 Feb 12];18(6):505-9. Available from: http://dx.doi.org/10.1136/qshc.2007.025726

10. Australian Commission on Safety and Quality in Health Care. National Standard for User-applied Labelling of Injectable Medicines, Fluids and Lines [Internet]. Sydney: ACSQHC, 2015 [cited 2019 Mar 17]. Available from: https://www.safetyandquality.gov.au/wp-content/ uploads/2015/09/National-Standard-for-User-Applied-Labelling-Aug-2015.pdf

11. Balzer F, Wickboldt N, Spies C, Walder B, Goncerut J, Citerio G, et al. Standardised drug labelling in intensive care: results of an international survey among ESICM members. Intensive Care Med [Internet]. 2012 [cited 2018 Feb 12];38(8):1298-1305. Available from: http://dx.doi. org/10.1007/s00134-012-2569-1

12. Koerich MS, Backes DS, Scortegagna HM, Wall ML, Veronese AM, Zeferino MT, et al. [Care technologies in health and nursing and their philosophical perspectives]. Texto Contexto Enferm [Internet]. 2006 [cited 2018 Feb 12];15(Esp):178-85. Available from: http://dx.doi. org/10.1590/S0104-07072006000500022 Portuguese.

13. American Society of Anesthesiologist. Statement on labeling of pharmaceuticals for use in anesthesiology [Internet]. Washington (DC): 2015 [cited 2018 Feb 12]. Available from: https://www.asahq.org/standards-and-guidelines/ statement-on-labeling-of-pharmaceuticals-for-use-in-anesthesiology

14. Standard specification for user applied drug labels in anesthesiology ASTM designation: D 4774-94, annual book of ASTM standard. Philadelphia: American Society for Testing and Materials, 1994.

15. Pessalacia JD; Silva LM; Jesus LF; Silveira RC; Otoni A. [Nursing team performance in picu: a focus in humanization]. R Enferm Cent O Min [Internet]. 2012 [cited 2018 Feb 12];2(3):410-8. Available from: http://dx.doi.org/10.19175/recom.v0i0.275 Portuguese.

16. Padilha KG; Kitahara PH; Gonçalves CC; Sanches AL. [iatrogenic occurrences with medication in i.c.u: nurse's procedures and feelings]. Rev Esc Enferm USP [Internet]. 2010 [cited 2018 Feb 12];36(1):50-7. Available from: http://dx.doi.org/10.1590/S0080-62342002000100008 Portuguese.

17. Kothari D; Agrawal J. Colour-coded syringe labels: a modification to enhance patient safety. Br J Anaesth [Internet]. 2013 [cited 2018 Feb 12];110(6):1056-8. Available from: http://dx.doi.org/10.1093/bja/aet140 
18. Silva AEBC, Cassiani SHB. Prospective risk analysis of the anti-infective medication administration process. Rev Lat Am Enfermagem [Internet]. 2013 [cited 2018 Feb 12];21(Spec):233-41. Available from: http://dx.doi.org/10.1590/S0104-11692013000700029

19. Marques TC, Reis AMM, Silva AEBC, Gimenes FRE, Opitz SP, Teixeira TCA, et al. [Antimicrobial drug administration errors identified in brazilian multicentric study]. Rev Bras Cienc Farm [Internet]. 2008 [cited 2018 Feb 12];44(2):305-14. Available from: http://dx.doi.org/10.1590/S151693322008000200016 Portuguese.

20. Burdeu G, Crawford R, van de Vreede M, McCann J. Taking aim at infusion confusion. J Nurs Care Qual [Internet]. 2006 [cited 2018 Feb 12];21(2):151-9. Available from: http://dx.doi.org/10.1097/00001786-200604000-00011

21. Franco JN, Ribeiro G, D'Innocenzo M, Barros BPA. [Perception of the nursing team about causes of errors in the administration of medication]. Rev Bras Enferm [Internet]. 2010 [cited 2018 Feb 12]; 63(6):927-32. Available from: http://dx.doi.org/10.1590/S003471672010000600009 Portuguese.

22. Belela ASC, Pedreira MLG, Peterlini MAS. [Medication errors in Pediatrics]. Rev Bras Enferm [Internet]. 2011 [cited 2018 Feb 12];64(3):563-9. Available from: http://dx.doi.org/10.1590/S0034-71672011000300022 Portuguese.

23. Beccaria LM, Pereira RA, Contrin LM, Lobo SM, Trajano DHL. Nursing care adverse events at an intensive care unit. Rev Bras Ter Intensiva [Internet]. 2009 [cited 2018 Feb 12];21(3):276-82. Available from: http://dx.doi.org/10.1590/S0103-507X2009000300007

24. Machado AF, Pedreira MLG, Chaud MN. Adverse events related to the use of peripheral intravenous catheters in children according to dressing regimens. Rev Lat Am Enfermagem [Internet]. 2008 [cited 2019 Mar 14];16(3):362-7. Available from: http://dx.doi.org/10.1590/ S0104-11692008000300005

25. Collares PM. Innovation of prenatal care from a user-centered technology. Interface (Botucatu) [Internet]. 2014 [cited 2018 Feb 12];18(50):625-6. Available from: http://dx.doi.org/10.1590/1807-57622014.026

26. Wassef F, Sinz EH, Prozesky J, Martin D, Dyer AM. Using improved visual technique to reduce drug administration errors in the operating room. Anesthesiology. 2008;109: A758. 